\title{
1. Concepts, terms, structure
}

\section{INTRODUCTION}

Aristotle's METAPHYSICS opens with the words: "All men by nature desire to know," apparently an inherent human need and basic condition of life. "Ignorance is the curse of God, knowledge the wing wherewith we fly to heaven," says Shakespeare, and Molière, by way of the Master of Philosophy, draws the natural conclusion that "without knowledge, life is no more than the shadow of death." Professor Michael Dertouzos recasts this axiom in modern terms with regard to information, the primary source of knowledge: "Information, unlike food, shelter, health or energy, is not a primary factor to human survival. It is, however, necessary immediately after these basic factors, for it helps us plan and carry out actions aimed at satisfying our most basic necessities." 1

The elementary character of information in all important spheres of life has brought human culture frequently to regard it as part of the public realm. "The general rule of law," said Brandeis, "is that the noblest of human productions - knowledge, truths ascertained, conceptions and ideas become, after voluntary communication to others, free as the air to common use."2

What is information? We tend to regard information intuitively as inclusive of all types of data. Information, in this sense, is constantly being created and concerns virtually every topic. ${ }^{3} \mathrm{~A}$ considerable amount of it is worthless, as for example a casual stare at a random point in space. Significant parts of information serve no other purpose than to

1 Hearing on S. 240 before the Subcomm. on Criminal Justice of the Comm. on the Judiciary, 96th Cong., 2nd Sess. 38 (1980) (Statement of Prof. M. Dertouzos).

2 International News Service (INS) v. Associated Press, 248 U.S. 215, 250 (1918) (Justice Brandeis). See also the aphorism "Information wants to be free," Roger Clarke, "Information Wants to be Free ...," http://www.rogerclarke.com/ II/IWtbF.html (seen Mar. 2, 2015).

3 Harley C. Shands, Outline of a General Theory of Human Communication: Implications of Normal and Pathological Schizophrenics, in COMMUNICATION: CONCEPTS AND PERSPECTIVES, 97, 105 (Lee Thayer ed., 1967). 
satisfy the personal curiosity of the individual interested in various objects, phenomena and events. But large portions are by nature also a source of power, as evident from the fact that information is commonly applied to decision making, ${ }^{4}$ and is considered to be "the lifeblood that sustains political, social and business decisions." 5

The power inherent in the control of information has long been acknowledged. Society has always valued experts and advisors as creators of knowledge, and has granted them special status. Francis Bacon's words, "nam et ipsa scientia potestas est" ("for knowledge, too, is itself power") 6 reflect a long history of human experience. With the intense use of information that has become an integral part of modern life, the power inherent in its control has reached a new zenith. ${ }^{7}$

The purpose of this study is to construct a primary general theoretical structure and a conceptual system that describe the forms and terms of protection of confidential information through substantive criminal law. After briefly examining the concept of information as presented in information theory, we focus on the substance and extent of protection. To do so, we develop a structure of models that reflects the important types and patterns of criminal law provisions aimed at protecting confidential information and its sources from unauthorized use or disclosure. $^{8}$

4 Marshall C. Yovits \& Ernest M. Stokely, Generalized Information Systems: Consequence for Information Transfer, in PEOPLE AND INFORMATION, 3, 9 (Harold E. Pepinsky ed., 1970).

5 Anne W. Branscomb, Global Governance of Global Networks: A Survey of Transborder Data Flow in Transition, 36 VAND. L. R. 985, 987 (1983).

6 Francis Bacon, De Haresibus, in Meditationes SACRAE (1597).

7 Infra $\$ 3.1$ - The Information Age.

8 A short remark concerning style: Throughout this study I use "man," "he," and "his" to signify man and woman, he and she, his and her - in other words all people "whenever there is no need to distinguish them," as JACQUES BARZUN says (FROM DAWN TO DECADENCE: 500 YEARS OF WESTERN CULTURAL LIFE, 1500 TO THE PRESENT, 82 (2000), http://www.thedivineconspiracy.org/ Z5218P.pdf (seen Mar. 2, 2015)). Barzun makes a spirited argument against the clumsy repetition of "man and woman" and its attendants "his and her," which undercuts the rhythm and smoothness of the prose and adds emphasis where no emphasis is needed (ibid., at 82-85). 


\section{THE CHARACTER OF INFORMATION}

\subsection{Information and Sources of Information}

The term "information," as used in the legal context, is derived from the general sociocultural notions of information, and to some extent from information theory. Although the legal profession does not commonly use these general expressions and concepts, and tends to examine information in its everyday intuitive meaning, familiarity with these general terms can help clarify the legal context of information.

There is no generally accepted definition of the term "information," and the formulation of such a definition in the current scientific environment is unlikely. ${ }^{10}$ The term is used differently in various disciplines, ${ }^{11}$ and it appears to be one of those interdisciplinary concepts that "perversely remain[s] multiple, ambiguous, imprecise, and above all unstable and open." 12

\subsubsection{General characteristics}

Concepts that resist definition by a set of conclusive, necessary and sufficient conditions can at times be described partially by some characterizing elements. "Selection" or "choice" is commonly viewed as a basic element in descriptions of the essence of information, ${ }^{13}$ and expressions like "sign" (or "signal"), "symbol" and "message" are often used to add clarity to the meaning of the term in a communicative context.

Information theory, dating back to the mid-20th century, has endowed the concept of information with new and broad significance, and has formulated mathematical rules to explain the flow of information in

9 Some scholars claim that more than one hundred different definitions of the terms "information" and "communication" are in use. E. Ploman, Trans Border Data Flows: The International Legal Framework, 3 COMPUTER L. J. 551, 553 (1982).

10 Preface to People And Information supra note 4; RAdU J. Bogdan, Grounds For Cognition: How GoAl-Guided BeHAVIor SHAPES THE Mind, 53 (Hillsdale, 1994).

11 Robert M. Losee, A Discipline Independent Definition of Information, 48 J. AM. SOC. INFO. SCI. 254, 256-58 (1997).

12 John H. Flavell, Patricia H. Miller \& Scott A. Miller Cognitive DeVelopment, 2 (4th ed., 2002).

13 In the broad meaning of the terms "choice" or "selection," namely the restriction of a reference set to a certain subset. COLIN CHERRY, ON HuMAN Communication: A Review, A Survey, And A Criticism, 244-45 (3rd ed., 1978). 
communication and information systems. Information theory does not address itself to the semantic content of the information, that is, to its "import" or "cargo," and cares not a whit whether a piece of information is true, false, important or, indeed, whether it makes sense at all. Rather, it establishes tools that make possible the quantitative measurement of information and the evaluation of the capacity of different systems and channels to receive, store, encode, process and transmit information. ${ }^{14}$ The theory defines a signal as the carrier of a measurable quantity of information, irrespective of its content. According to information theory, information is the result of a choice made between signals that have a communicative value. ${ }^{15}$ The measure of information contained in the selection of a signal increases as the probability of its occurrence decreases. ${ }^{16}$

The implications and importance of the principles of the information theory and the mathematical models based on them exceed their original meaning developed within the framework of communication engineering, ${ }^{17}$ and serve as a basis for further theoretical development and for additional applications in other scientific disciplines. ${ }^{18}$

14 The principal developer of the theory is Claude E. Shannon, in his article A Mathematical Theory of Communication, 27 Bell SyST. TECH J. 379, cont. 623 (1948). For further development of the theory see Claude E. SHANNON \& WARREN WeaVer, THE MATHEMATICAL THEORY OF COMMUNiCATION (1949). For additional research see INFORMATION THEORY: 50 YEARS OF DISCOVERY (Sergio Verdu \& Steven W. McLaughlin eds., 1999); Thomas M. Cover \& JoY A. THOMAS, ELEMENTS OF INFORMATION THEORY (2nd ed., 2006).

15 When receiving information we are faced with alternatives that impose a choice. A process of selection conveys information because it illuminates the uncertainty involved in the question of which subset of signals we actually received. J. ACZEL \& Z. DAROCZY, ON MEASURES OF INFORMATION AND THEIR CHARACTERIZATION, 2-3 (1975); CHERRY, supra note 13, at 169-72.

16 Commonly, information is measured in bits (binary digits). One bit is equivalent to the choice between equally likely choices. ACZEL \& DAROCZY, ibid., at 3-4; ALFRED RENYI, A DiARY ON INFORMATION THEORY, 9 (1987).

17 See the use of terms such as "encoding," "storage" and "noise," SilviU GUIA-SU, INFORMATION THEORY WITH NEW APPLICATIONS, 170-80 (1977); RENYI, ibid., at 6.

18 Basic concepts of information theory are applied in various areas of life science, medicine, environmental science, linguistics, social science and psychology. See The Study of Information: InTERdisciplinary Messages (Fritz Machlup \& Una Mansfield eds., 1983); COVER \& THOMAS, supra note 14, at 1-5. 


\subsubsection{Sociocultural context}

Most disciplines do not fully adopt the concepts and emphasis of information theory, but prefer to stress other aspects of the term "information" and to use it in ways that better reflect their needs. ${ }^{19}$ So does the present study, which stresses the sociocultural context and applies a more commonplace characterization of information, as an epistemological concept.

Despite differences in emphasis, the general rules of information theory apply to the sociocultural angle of information as well. ${ }^{20}$ The flow of information in the human environment can also be expressed using the terms of information theory: systems that can produce, process and exchange signals. ${ }^{21}$ The differences between the approaches are fundamental, however, and strike at the heart of the issue. Both information theory and sociocultural approaches agree that information is something that travels between a source and a receiver. But whereas information theory is concerned with the neutral, independent meaning of the flow, the sociocultural perspective focuses also, often mostly, on the thing itself that travels. From the sociocultural perspective, it matters greatly not only whether an item of information makes sense, but also what it means.

The sociocultural focus limits the discussion to data (signals) perceived by human consciousness. Information, in this sense, is an expression of a conjunction between an interested individual and different sources of information on one hand, and the resulting change in individual consciousness on the other. ${ }^{22}$ Thus, information becomes a human phenomenon of internalization that can serve as a basis for possible actions..$^{23}$ It is a dimension of social reality and a bridge between human consciousness and the external world. ${ }^{24}$

19 For an analysis of various perceptions of this complex term and approaches to it see R. Capurro \& B. Hjørland, The Concept of Information, 37 AnN. Rev. InFo. SCI. TECH. 343 (2003).

20 Capurro \& Hjørland, ibid., at 360.

21 Capurro \& Hjørland, ibid., at 367-68.

22 Charles K. West, The Social and Psychological Distortion of INFORMATION, 7 (1981); Yovits \& Stokely, supra note 4, at 15-16.

23 Fritz Machlup, Semantic Quirks in Studies of Information, in THE STUDY OF INFORMATION: INTERDISCIPLINARY MESSAGES, 641, supra note 18, at 660.

24 Restricting information to data perceived by human consciousness excludes two important information systems: (a) the biological system that enables the continuation of life through genetic information-carrying processes (the DNA code); and (b) messages issued by flora and fauna, such as voices, colors and smells, which enable communication within the fauna and between the flora and fauna. Data concerning these non-human interactions are received 
In the broadest sense, the first axiom of a general perception of information is that similarly to matter and energy, in its potential expression, information is a basic property of the universe. ${ }^{25}$ Sources of information are present in every aspect of the world and exist in every place, at all times, in everything. Every object, phenomenon or occurrence has, by its mere existence, a stimulating effect on the human consciousness, an immanent attribute to become an object of human interest. ${ }^{26}$ This stimulating effect should be distinguished from the actual existence of the objects, phenomena or occurrences as real substances. Usually, sources of information are external to the interested individual, but the term may include internal observations regarding the self, such as heartbeats or stimuli like pain.

Human consciousness serves as a mediating mechanism that turns sources of information (potential information) into information and eventually ascribes a sociocultural meaning to them. Phenomena reflected by the universal law of gravity or the relations expressed in the Pythagorean theorem existed before they were formulated by Newton and Pythagoras, but they did not have any sociocultural significance before their absorption into human consciousness. One scholar termed the connection between a source of information and consciousness information-as-process, and "having the quality of imparting knowledge or communicating information," information-as-thing. ${ }^{27}$

In a sociocultural sense, information relates to the analysis of its content, to the examination of signals as sensory data about objects, phenomena or occurrences, ${ }^{28}$ and the ascription of meaning to these

and comprehended by the human consciousness; they are perceived as regular information (infra Ch. $4 b$ b 4.2.2.2.2 - Genetic Information).

25 Tom Stonier, Toward a New Theory of Information, 17 J. INFO. SCI. 257, 258 (1991); Tom Stonier, Information as a Basic Property of the Universe, 38 BiOSYSTEMS 135 (1996).

26 William Mock, On the Centrality of Information Law: A Rational Choice Discussion of Information Law and Official Transparency, 17 J. COMP. \& INFO. L. 1069, 1075-76 (1999).

27 Michael K. Buckland, Information as Thing, 42 J. AM. Soc. INF. SCI. 351 (1991). For a somewhat different approach, Mock, ibid.

28 In addition to quantitative theory, research is also being conducted on the semantic aspect of information. Yehoshua Bar-Hillel \& Rudolf Carnap, Semantic Information, 4 BRIT. J. PHIL. SCI. 147 (1953). Bar-Hillel is cautious in evaluating the contribution of information theory to linguistics. YeHOSHUA BAR-HILLEL, Aspects of LANGUage: Essays AND LeCtures on Philosophy of LANGUAGe, Linguistic Philosophy And Methodology of Linguistics, 289-301 (1970). 
data. $^{29}$ This facet emphasizes the inspection of the qualitative aspects of information, as opposed to the quantitative analysis of information theory and of the scientific applications based on it. ${ }^{30}$

Conscious reception of data creates information in the broadest abstract sense and establishes connections between human consciousness and objects, phenomena or occurrences around it. But in the sociocultural sense, in most cases data reception as such is of limited practical significance. The fundamental social value of the conscious data reception derives, first and foremost, from the fact that the data received are the most important source of knowledge. ${ }^{31}$ It is difficult to distinguish between mere reception of data and their absorption and decoding in the consciousness within a framework of connections, contexts and patterns of classification that ascribe meaning to them. ${ }^{32}$ The operation of human consciousness by which information reaches its full sociocultural potential is a continuous process, starting with data reception in the wake of

29 The INTERNATIONAL ENCYCLOPEDIA OF INFORMATION AND LIBRARY SCIENCE, 244 (2nd ed., John Feather \& Paul Sturges eds., 2003) defines information as "data that has been processed into a meaningful form."

30 Some social science theories combine ideas of quantitative measurement (information theory) with the examination of the inherent quality of the data. KeITH J. DEvLIN (Logic AND Information (1991)) measures information in units called infons, quasi quantum particles of information. He regards information as a measure of the degree of order in a system. $C f$. the concept of "memes," coined by zoologist RichaRd DAWKins (THE SElFish GENE (1976)), units of cultural measurement containing the footprints of culture in the same way that genes contain the footprints of life. A meme is an idea, behavior or skill that can be transferred from person to person by imitation. JACK M. BALKIN, Cultural Software: A TheORY OF IDEOlOGy (1998).

31 Knowledge can have additional sources, like proprioception and mental inner-consciousness processes, including thoughts, conclusions and imagination. Proprioception, which relates to ex-conscious phenomena like your own heartbeats or pain, may be regarded as a source of information, but reference to mental and inner-conscious phenomena like thoughts as sources of information would turn everything into such sources.

32 Gordon L. Miller's description and analogy, in The Concept of Information: A Historical Perspective on Modern Theory and Technology, in INFORMATION AND BEHAVIOR, vol. 2, 27, 40 (Brent D. Ruben ed., 1988): "Both machine and human 'information processing' are apparently often envisioned in somewhat of a factory metaphor, in that pieces of 'raw data' ... are thought to be taken in by the mechanical or human 'factory' and processed into some sort of finished product, such as lists, reports and analyses for machines, and percepts, concepts and memories for humans." 
interest and following with an interpretation of the received data. ${ }^{33}$ The body of knowledge that an individual possesses contains additional constituents that are not based on extrinsic information. The texture of acquired assets, like conceptions, values, symbols, presumptions, analogies, experiences and beliefs, as well as the structure of immanent qualifications, like understanding, emotions, imagination, intuitions and the power of abstraction, are also interwoven into the complex of knowledge. Clearly, all knowledge that emerges from information or from other sources can be embodied in signals, and these signals may constitute a basis for additional information because other individuals may perceive them in a context of inquiry. Just as information is a possible source of knowledge, knowledge is also a source of information.

The close conceptual interrelationship between information and knowledge is mirrored in its application to common intuitions and daily language. Both terms fail to draw a clear boundary between themselves. Law, as a practical social discipline, reflects this analytical and functional blur. To establish a borderline, the concept of information in its sociocultural sense is limited in this study to the reception of signals by a human consciousness.

In this sociocultural sense, information is of an abstract nature and a relative concept, the substance and content of which are a function of the quality and scope of the interest a person exercises. The relative nature of information follows from its reliance upon the reception process that forms it, ${ }^{34}$ which may often cause dissimilarities between items of information created by different individuals observing the same reality, and reflect variations in the nature, quality and extent of reception or interpretation among them. Formation of information by one individual but not by another does not necessarily indicate a disparity in their exposure to phenomena, occurrences and objects. The difference may follow from dissimilar inquiries made about the same object, which capture each individual's interest from a different perspective. The information thus formed may also contribute differently to each individual's knowledge, owing to the interaction between the newly absorbed

33 Bertram C. Brookes, The Foundation of Information Science, Part 1: Philosophical Aspects, 2 J. INFO. SCI. 125, 131 (1980). An echo of this chain of occurrences in reverse order is found in the verses of T.S. Eliot: "Where is the wisdom we have lost in knowledge? Where is the knowledge we have lost in information?" (The Rock II).

34 Fred I. Dretske, KNOWLedge And the Flow of Information, 80-81 (1981); Mosano Toda, About the Notions of Communication and Structure: A Perspective, in Communication: Concepts And Perspectives, 25, 34-38. 
information and his understanding, knowledge, experience, judgment and other characteristics. ${ }^{35}$ The relativity of information at the doctrinal level does not negate, however, the existence of joint interests. Such common denominators are a prerequisite of any sociocultural framework.

\subsection{Communicative Messages}

Sources of information are often captured by an individual in order to transfer them to others, creating a communicative message. Information stored in a consciousness may be subjected to a similar process. A communicative message is a separate source of information, added to the original source that served as its basis. Communicative messages are expressed by linguistic and non-linguistic representations. The linguistic means of representation are languages, closed systems of agreed-upon symbols with a structured syntax. ${ }^{36}$ The most frequently occurring forms of language, vital to the evolution of culture, are speech and writing. But languages also appear in other acoustic and visual forms, for example Morse code and sign language. Non-linguistic means of representation are the remaining modes of communication and information storage, most prominently photography, sound, video recording and sketching. Sounds, gestures and touch can also be used as signs that serve as means of representation of a communicative message. Photography, sound, and video recording are based on the duplication of signals that constitute the object of the message. Sketching expresses the message graphically. Similarly to linguistic means of communication, sketching is based on agreed-upon symbols, but unlike language it lacks syntactic organization. A communicative message expressed in one mode can usually be translated into a new message expressed by other means of representation, either by the individual who formed it or by another interested party. ${ }^{37}$

Choice constitutes a basic element in the construction of all communicative messages. The creation of communicative messages in nonlinguistic modes (photography, sound recording) involves an obvious selection process, based on focusing on a set of signals. In linguistic

35 WEST, supra note 22, at 6-11; CHERRY, supra note 13, at 262, 299.

36 For the general foundations of the theory of signs see THOMAS L. SHORT, Peirce's Theory of Signs (2007); Stephen Levinson, Pragmatics (1983). For a brief presentation of the subject see CHERRY, supra note 13, at 219-28.

37 Naturally, a translation from one language to another involves an interpretive effort, which may have implications for the accuracy of the transformation. 
form, an additional act of selection takes place. For example, writing involves choosing conventional letters, letter combinations and syntactic structures from the general framework of the language.

Two stages separate a communicative message from the object, occurrence or phenomenon that it reflects. In the typical case, the first stage is the formation of information, either by a sensual reception through physical systems or a mental-perceptive process not derived from direct observation (for example, the theoretical development of a mathematical formula). The second stage is the transformation of the information into a communicative message through representational means. ${ }^{38}$ The order of the stages may differ or the two may occur simultaneously, as for example the concurrent filming and observation of an event. Frequently added to both stages are operations involving the processing and merging of the pre-existing pieces of information and knowledge.

The mechanism of acquiring information through communicative messages produces several levels of decoding. This variance derives from differences in the nature of reception and in the individuals' decoding abilities. The basic level is fully disclosed information from the perspective of the interested individual, as for example when listening to a familiar language or reading text in it. Another level of information acquisition concerns the category of potentially decoded information, involving cases in which the individual has received the chosen signals and is aware of their informative potential, but does not know how to decode them, as in the case of receiving an encoded message or listening to a foreign language. Subsequent revelation of the code reclassifies the case into the first category. Reception of signals, when the recipient is unaware of their nature as a message expressed by means of representation, constitutes a third category of information acquisition. Hieroglyphics, for example, viewed by an individual who is ignorant of their nature, may appear as a series of small paintings. A subsequent process of deciphering, or even mere awareness of their informative potential, leads to a reclassification of the event into either the first or the second mentioned categories.

\subsection{Interrelation}

The importance of communicative messages lies, first and foremost, in their use as primary sources of information and knowledge about an

38 A conscious process may produce a circular relationship between the two stages. Each of the stages can serve as a point of departure for the creation of information and each can lead to the other. 
existing or a possible reality. ${ }^{39}$ A prominent part of human knowledge is acquired through the reception and processing of communicative message signals expressing information and frequently propositions, as distinguished from the direct observation of objects, occurrences or phenomena referred to in the messages. ${ }^{40}$ Receiving a communicative message regarding the height of a mountain is the same as knowing the height of the mountain and not merely holding the information contained in a proposition about that detail. This facet of information emphasizes its practical aspect.

Uncertainties about the quality of the communicative message add to doubts about the process of knowledge formation ${ }^{41}$ based on information. In addition to questioning reception quality and decoding accuracy, the receiver of a communicative message also examines its context, including the purpose, seriousness and reliability of the transmission. ${ }^{42}$ The examiner may analyze the trustworthiness of the transmitter, the context of the creation of the message and the surrounding circumstances. In the example of mountain height, one receives the information differently when listening to an amateur mountain climber's impression, reading the data in a professional journal or listening to a child's description of the mountain.

To summarize the interrelations between information, sources of information and communicative messages, attention must be paid to the bilateral connections between each notion and the other two (see Figure 1.1). From a sociological perspective, the three terms form a triangular structure, with each term at one vertex. The main parameters that form the inter-concept relationship are: (a) the ability to derive one concept from the other or to turn it into the other through a conscious action (that is, information from the source of information, communicative message from information, communicative message from the source of information, and so on); and (b) the fact that at times one concept is a type or

39 WEST, supra note 22, at 5.

40 Margaret Morse, Virtualities: Television, Media Art And CyberCulture (TheORIES OF CONTEMPORARY Culture) (1998), who regards the reduced dependence on personal experience as one of the characteristics of cyber culture.

41 These doubts include uncertainties about the veracity of the data received (CHERRY, supra note 13, at 198-205) and about its validity (ROBERT AUDI, EPISTEMOLOGY: A CONTEMPORARY INTRODUCTION TO THE THEORY OF KNOWLEDGE (3rd ed., 2011).

42 Anton Vedder \& Robert Wachbroit, Reliability of Information on the Internet: Some Distinctions, 5 ETHICS AND INFO. TECH. 211 (2003). 


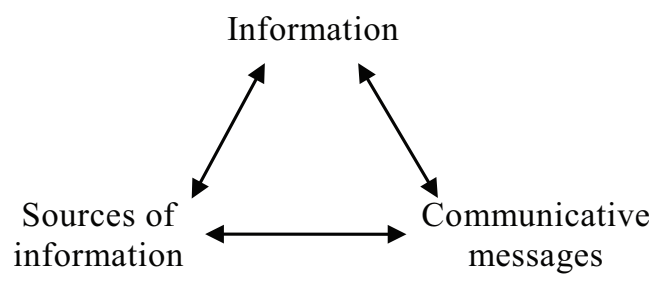

\section{Figure 1.1 Relationship between information, its sources and communicative messages}

subset of another (the communicative message is a form of source of information).

The distinctions between information, sources of information and communicative messages may be relevant to the user or to the holder of the information (or of the substance constituting the source of information). From the point of view of every additional individual who wants to acquire the information, however, these are all sources of information.

\subsection{The Legal Perspective}

Describing information as deriving from the subjective relationship between an individual and an object of his interest, and the fact that information is part of a group of abstract notions does not diminish the interest of the law in various aspects concerning it. The relationship, the formation of information that ensues and the communicative messages are all objective realities. Aspects of these realities and their interrelations and applications are of concern to the law. The law often faces situations in which sources of information, communicative messages and mere information are relevant components of the situation at hand. This is usually the case when the circumstances related to the formation of information or to the acquisition or transfer of a communicative message infringe upon protected values (for example, peeping, eavesdropping, commercial espionage, and so on).

The terms "information," "sources of information" and "communicative messages," and especially their bilateral relations, have seen little conceptual analysis in the legal arena, where often no distinction is made between them. The reason is simple. Information expressed by communicative messages, commonly linguistic ones, often undergoes a process of materialization in our consciousness. After being transformed into communicative messages, the sources of information are recognized as information in the everyday sense of the term, and their perception as 
symbols expressed by means of communication requiring conscious interpretation, becomes blurred. In its everyday meaning, the contents of communicative messages such as discussions, books, newspapers or databases are considered independent objective substances (informationas-thing), detached from the consciousness of any individual. ${ }^{43}$ In these many cases, information and communicative messages (information-inprocess and information-as-thing) are viewed as synonymous, and in the human perception the two concepts merge into a single substance.

In some cases, however, the law preserves the separate status of the creation of information as a connection between consciousness and the source of information, which is not a communicative message. For example, criminal eavesdropping can take shape only by shadowing and trailing an individual, turning him into a source of information. Monitoring a person by illegally obtaining communicative messages about him can harm his privacy or form an offense concerning the illegal acquisition of information, but these are different offenses.

The interest of the law in communicative messages has intensified significantly over the years, and in many cases these messages become a basis for legal actions and transactions. In the context of this work, communicative messages are a main object of protection.

\section{THE VALUE OF INFORMATION}

\subsection{The Information Age}

\subsubsection{The new socio-technological environment}

Never before has there been such an immense quantity of accumulated information expressed in an assortment of regular and electronic communicative messages, including writings, electronic data, recordings, photographs and drawings covering a wide range of issues and fields. Nor has there ever been such a surge in the production, storage, processing and distribution of that information.

More than 130 years ago, Benjamin Disraeli pointed out that information is the key to success: "As a general rule, the most successful man in life is the man who has the best information." 44 Seventy years later,

43 H. Franken, J.C. Arnbak, J.M.A. Berkvens, B.K. Brussaard, A.W. KoERS, I.TH.M. SNELlEN \& A.H.J. SCHMidT, InFORMATION TECHNOLOGY AND THE LAW, 5 (K.M.M. Hudson-Brazenall Trans., 1991).

44 BENJAMin DisRaEli (1st Earl of Beaconsfield), ENDYMION, ch. 36 (1881), http://www.gutenberg.org/files/7926/7926-h/7926-h.htm (seen Mar. 2, 2015). 
Norbert Wiener, the father of cybernetics, stated that "to live effectively is to live with adequate information." 45 These statements are even more valid today. At the start of the new millennium, in industrialized societies, without adequate control over sophisticated information-based environments it is becoming increasingly difficult to conduct a normal daily life.

In all its forms and representations, information is more than a personal asset or the object of innumerable commercial transactions: it is a driving force that has significant influence over social movements and the political infrastructure. It is vital to the efficient functioning of government, economic, scientific and other systems that shape modern society, the quality of life and the welfare of individuals. ${ }^{46}$ In short, we are currently experiencing the strength and intensity of the "information revolution."

The information revolution received a considerable boost from socioeconomic changes, including the expansion and growth of privacy and intellectual property, ${ }^{47}$ and from technological developments, primarily in the area of computer and communication technologies. The present study addresses both categories of changes, especially the socioeconomic one. At this point, a few remarks about technological development are in order.

Technological development increased dramatically the availability of all types of communicative messages. The growth in mass communication and the development of the Internet and of social networks have added a new dimension to the concepts of computerization and communication. Computer technology has provided the capacity for the creation of gigantic databases and has allowed high-speed data processing. Concurrently, advanced replication techniques have made the term "original document" often lose its meaning. A great portion of official and business transactions, as well as many of our personal daily

45 Norbert Wiener, Human Use of Human Beings: Cybernetics and SOCIETY, 18 (1954).

46 US authorities have attributed great importance to information science and communication at both the national and international levels. Already in the early 1980s, officials stated that communication and information technologies represent the leading edge of US strength. George W. Coombe \& Susan J. Kirk, Privacy, Data Protection, and Transborder Data Flow: A Corporate Response to International Expectations, 39 Bus. LAw. 33, 35 (1983).

47 For further discussion and analysis of these values and terms, infra notes 70-76 \& 82-97 and text accompanying, infra Ch. 2 § 3 - MetaphoricConceptual Spaces, and infra Ch. $4 \mathrm{a} \$$ 3.3.2.2 - The Economic Espionage Act, and Ch. 4b $\S 4.1 .2 .2$ - Computers and Internet: Databases, Data Mining and Social Networking. 
activities, is collected, documented and preserved by computer technology as communicative messages, ready for instant retrieval and processing. Communication technology, assisted by satellites and other means of transmission, has permitted access to these messages at all times, even from remote sites.

Rapid and extensive changes in computer and communication technology have reshaped cultural norms and practices, ${ }^{48}$ and their cumulative effect has become significant in the establishment and maintenance of political, economic and social power. As information becomes less costly and more easily available, we become increasingly dependent on it and on those who control its selection, aggregation and transfer. The overwhelming practical influence of information on today's life is also reflected in changes in terminology. The economy of the developed and industrialized nations is often referred to as the "information economy," 49 and our age is called the "information age," "information era" or "net era" 50 - a successor to the industrial and post-industrial societies. ${ }^{51}$ This should not be perceived merely as a reflection of a modern, white-collar, service-based economy. The attitude toward information has undergone a far more significant change: the "information economy" does not regard information strictly as an instrument by which assets are acquired and

48 David Bell, An Introduction to Cybercultures (2001); Youth Culture and Net Culture: Online Social Practices (Elza Dunkels, Franberg Gun-Marie \& Hallgren Camilla eds., 2011).

49 For some earlier uses of the term see R.G. Hammond, The Misappropriation of Commercial Information in the Computer Age, 64 CAN. B. REV. 342, 346 (1986). The main economic significance of information is that it increases productivity. MARK U. PORAT, THE INFORMATION ECONOMY, DEFINITION AND Measurement, Special Pub. 77-12(1) (US Dep't of Commerce, 1977); FriTZ Machlup, Knowledge: Its CREATION, Distribution AND ECONOMIC SignifiCANCE, vol. 3 - THE ECONOMICS OF INFORMATION AND HuMAN CAPITAL, 178 (1984). For recent uses of the term see OECD GUIDE TO MEASURING THE INFORMATION SOCIETY 2011, http://browse.oecdbookshop.org/oecd/pdfs/free/ 9311021e.pdf (seen Mar. 2, 2015).

50 Fritz Machlup, The Production and Distribution of KNOWLEdGe in THE United States (1962); Christian Fuchs, InTERnet AND SOCIETy: SOCIAL TheORY IN THE Information Age (2008); MAnuel CASTells, The Information Age: Economy, Society And Culture, vol. 1: The Rise of the NETWORK SOCIETY (2nd ed., 2010).

51 Daniel Bell, The Coming of Post-Industrial Society: A Venture in Social Forecasting (1976); Third Century: AmericA AS A Post-Industrial SOCIETY (Seymour M. Lipset ed., 1996). 
transferred, but as a "primary asset itself." 52 Information, although not a regular natural resource, ${ }^{53}$ has become a key factor in the global production process, neutralizing to some degree the long-standing disadvantages that countries deficient in natural resources have faced before. In relations between individuals and corporations, as in relations between states, control of information translates into economic and social power.

Sociologists point out that the dominance of the information economy in modern Western society has caused a change in the social structure, and that "information workers," namely engineers and technicians, are replacing entrepreneurs as the leading social class. ${ }^{54}$ Individual creativity facilitated by communication technology is reflected also in the development of "commons-based peer production," which serves as a basis for the "networked information economy." Peer creation and dissemination of "user-generated content" on the Internet, characterized by effective cooperative efforts and a lack of commercial drive or insistence on property rights, has challenged to some extent the industrial information economy. ${ }^{55}$

Use of the Internet has caused changes also in social communication and in some social relationships. The Internet has become a central stage for individual expression, using communicative messages articulated in a variety of forms and means of representations. The Internet also consolidated the idea of a network community. Leisure-oriented and other social and professional networks of communication have expanded greatly, and new channels have come into existence where people can meet, be entertained, exchange ideas and solve problems. It is clear, however, that in general this virtual and remote web of connections is more abstract and less material than the world without computers and electronic communication used to be. Current trends indicate that clever and

52 Anne Wells Branscomb, Who Owns Information? From Privacy to Public ACCESS, 1 (1994).

53 Lawrence B. Solum, Questioning Cultural Commons, 95 CORNELL L. REV. 817, 827 (2010).

54 BeLl, supra note 51, at 125; Daniel Bell, The Social Framework of the Information Society, in The MicRoelectronics Revolution, 500, 523 (Tom Forester ed., 1980).

55 Yochai Benkler, The Wealth of Networks: How Social ProducTION TRANSFORMS MARKETS AND FREEDOM (2006), http://www.benkler.org/ Benkler_Wealth_Of_Networks.pdf (seen Mar. 2, 2015). 
sophisticated use of the net can be transformed into social, political and economic power. 56

\subsubsection{Response of the law to changes and developments}

The response of the law to these changes is not uniform, and depends primarily on the nature of the development that brought about the change. Generally, the law tracks sociocultural and economic changes closely as these processes emerge and develop. At times, the legal system precedes these changes and serves as their basis and starting point. But in most cases a feedback loop between the law and sociocultural or economic changes provides content to an ongoing interaction. The process of modification is slow and gradual, and it is tightly interwoven with the development process of the legal system, often serving to eliminate the sense that a gap exists between the prevalent social outlook and the legal situation.

This type of interplay is significantly weaker in the relations between the law and the exact sciences and technological developments. It is usually the law that responds to the scientific stimulus of inventions and advances. The law regulates the implementation of technology and scientific discovery, and naturally such regulation is possible only after the development or discovery has taken place. ${ }^{57}$

56 According to World Meters - Real Time World Statistic, over 3 milliards people worldwide, more than 40 percent of the world population, were Internet users as of March 2015, http://www.worldometers.info (seen Mar. 2, 2015). See also, Internet World Stats, Usage and Population Statistics, http://www. internetworldstats.com/stats.htm (seen Mar. 2, 2015).

57 In modern Western culture, only on rare occasions does the law attempt to direct scientific development in advance, through prohibitions, as for example in the cases of prohibiting or suspending human reproductive cloning and the performance of medical experiments on humans without authorization. At the same time, policymakers often influence and encourage certain directions in scientific research through the allocation of financial support.

For the prohibition on cloning see UNESCO Universal Declaration on the Human Genome and Human Rights, Art. 11 (29th Sess., 29 C/Res. 16 (1997)), http://unesdoc.unesco.org/images/0012/001229/122990eo.pdf (seen Mar. 20, 2015). The declaration was adopted by the General Assembly (G.A. Res. 152, U.N. GAOR, 53rd Sess., U.N. Doc. A/53/152 (1999)). For a list of states that have enacted laws prohibiting or imposing a moratorium on techniques of human cloning see UN EDUCATIONAL, SCIENTIFIC AND CUltural ORGanization (UNESCO), National Legislation Concerning Human Reproductive and Therapeutic Cloning (2004), http://unesdoc.unesco.org/images/0013/001342/134277e. pdf (seen Mar. 2, 2015). For the prohibition on medical experiments on human beings see WMA Declaration of Helsinki - Ethical Principles for Medical 
In the relations between law and technology the rate of change is usually faster than that between social and legal developments, and no gradual or interactive characteristics are present. The relations between the law and technological development are also characterized by a quantum-type change, with the law attempting to close the gaps created by technological development in leaps. ${ }^{58}$ Technological development is usually instantaneous and reaches the markets rapidly, often creating a need for quick legal response to regulate its various aspects. Any delay increases the sense of discrepancy between the advanced scientific reality and the legal system. ${ }^{59}$ By the time the usually cautious legal system closes one gap, quick technological advance may open up another. ${ }^{60}$

These basic patterns are evident also in the response of the law in the area of information. On one hand, the law is a full partner in the social process that gradually shapes the terms of privacy and intellectual property. On the other hand, vis-à-vis the technological reality in the area of information technology and computerized communication, the legislative process, and to some extent the judiciary, seem to be lagging behind as new gaps open up continually. ${ }^{61}$ This variance in the position of the law has also left its imprint on legal research concerning information. As far as social changes are concerned, the step-by-step processes and the gradual development of concepts stimulated a thorough interchange of ideas. As a result, a rich body of general-theoretical legal research on

Research Involving Human Subjects (adopted by the 18th World Medical Assembly, 1964, last amended by the 59th General Assembly, Korea, 2008), http://www.wma.net/en/30publications/10policies/b3/ (seen Apr. 13, 2014).

58 See the changes in the Abortion Law, 1967 in the UK (resulting in a 24-week abortion limit instead of the 28-week limit before the change, as a result of medical advances in neonatal care, which ultimately led to a reduction of the gestational upper limit). House of Commons, Science and Technology Committee, Scientific Developments Relating to the Abortion Act 1967, Twelfth Report of Session 2006-07, vol. 1, 9-26 (HC 1045-I, 2007), http://www.publications. parliament.uk/pa/cm200607/cmselect/cmsctech/1045/1045i.pdf (seen Mar. 2, 2015).

59 Christopher M. Holman, Copyright for Engineered DNA: An Idea Whose Time has Come?, 113 W. VA. L. REV. 699, 707 et seq. (2011).

60 For an analysis of why the law fails to keep up with emerging technologies, see Gary E. Marchant, The Growing Gap Between Emerging Technologies and the Law, in THE GROWING GAP BETWEEN EMERGING Technologies and Legal-Ethical Oversight: The Pacing Problem, 19, 23 (Gary E. Marchant, Braden R. Allenby \& Joseph R. Herkert eds., 2011).

${ }^{61}$ Shahid Khan, "Apps.Gov": Assessing Privacy in the Cloud Computing Era, 11 N.C. J.L. \& TECH. ON. 259, 281-82 (2010); Sonia K. McNeil (Note), Privacy and the Modern Grid, 25 HARv. J. LAW \& TECH. 219-24 (2011). 
intellectual property and privacy of information exists, in addition to a variety of books and articles concerning issues in these areas. But with regard to technological development, at times a significant portion of the research effort has been invested in addressing specific issues, limited in scope. The rapid succession of developments may have forced some legal scholars to devote a part of their energies to providing solutions to immediate problems as they arise. To some degree, this displaced the discussions of general subjects that normally establish and consolidate the theoretical basis for development, and which require a different time perspective and angle of examination.

\subsection{Legal Protection of Information}

\subsubsection{Nature of the protection}

The information revolution has created some lacunae in the legal infrastructure. Their extent varies from one legal system to another. The problem does not derive entirely from the relatively slow legislation mechanism or the conservatism of the law. Lack of experience and disagreements between adherents to different approaches are also responsible for the absence of social and legal consensus on information issues, ${ }^{62}$ and raise obstacles before the evolution of comprehensive legal and ethical norms.

In principle, however, the importance of information has been well established in modern law. Much legislation concerning information, both directly and indirectly, has been enacted in recent decades in North America and Western Europe, and legal research has explored a variety of aspects of information. This legal momentum continues, and scholars have even suggested the formulation of a separate legal branch pertaining to information and media law. ${ }^{63}$ But it is unclear whether the legal aspects of information and communication have a unique common

62 Infra Ch. 4b $\S 4.1 .2 .1$ - General and Ch. 4a $\S 3.2$ - Basic Approaches.

63 For the development of the term "information law" used first in the early 1980s see Jon Bing, Information Law, 2 J. OF MediA L. \& PRACTICE 219, 235, 237 (1981). For recent uses of the term see Ulrich Sieber, The Emergence of Information Law: Objects and Characteristics of a New Legal Area, in LAW, INFORMATION AND INFORMATION TECHNOLOGY 1, 10 (Eli Lederman \& Ron Shapira eds., 2001). 
denominator or a "unifying coherence,"64 aside from subject matter, to justify the establishment of an independent legal field. ${ }^{65}$

The term "information" in its general, amorphous sense (as an association between an interested individual and a source of information, or a fusion between a consciousness and the attributes of objects, phenomena or occurrences that have, by their mere existence, a stimulating effect on the human mind) does not have a definite legal significance. From this point of view, information is a mere expression of the basic, selfexplanatory freedom of an individual to use his senses. At the same time, it is difficult to treat as one complex entity the many aspects and contexts in which information has legal significance and implications. The signals or data, that is, the content perceived by human consciousness, together with the circumstances surrounding its formation, processing, use or transfer, give information its sociocultural meaning. The interpretation of the information by the human consciousness turns it into understanding and knowledge, upon which conduct is based. The same understanding and knowledge may then create or affect ideas and interests ${ }^{66}$ that the law, as the framer of codes of behavior in society, needs to protect. In other words, only the social meaning of the content and the reflection of actions or omissions related to its formation, accumulation, use or transfer are subjects of legal concern.

Legal protection of information is a broad concept. Often it does not express a primary and independent protection of information or its sources (including communicative messages) as a separate social value. In many cases the protection is instrumental and indirect, intended to defend recognized rights, interests and values that are part of the basic fabric of the legal system, and which include, among others, privacy, interpersonal relationships, trust, national security and property.

\subsubsection{The rights, values and interests involved}

Privacy is considered a fundamental right in Western culture and its legal systems. ${ }^{67}$ The protection of information is so instrumental to this right

64 Neil M. Richards, The Information Privacy Law Project, 94 GEO. L.J. 1087, 1135 (note 293) (2006).

65 But cf. Bing, supra note 63, at 235-37; George B. Trubow, Information Law Overview, 18 MARShall L. ReV. 815 (1985).

66 For the process of turning information into knowledge see supra text accompanying notes 31-33.

67 For the legal historical bases of privacy see Samuel Warren \& Louis D. Brandeis, The Right to Privacy, 4 Harv. L. REV. 193 (1890); Ken Gormley, One Hundred Years of Privacy, 1992 WIS. L. REV. 1335. For basic approaches 
that the terms "personal information" and "information privacy" have become part of the protection of privacy. ${ }^{68}$ Although the definition of this information is far from being unequivocal, ${ }^{69}$ a personal connection of an individual to the information or source of information is a characteristic of privacy. Consequently, the object of the information may sometimes limit and at times deprive others of the ability to create or use that information without his consent.

The right to privacy, as reflected in the protection of information, is exemplified by the prohibition against the exposure by a caretaker of data about an individual's health without his consent. ${ }^{70}$ Other examples of the right to privacy, as reflected in the protection of sources of information, are the prohibition against photographing an individual on private premises and the prohibition against eavesdropping. ${ }^{71}$ Some European legal systems have widened the extent of the right to privacy to protect, in some instances, "personal" data concerning legal entities. ${ }^{72}$

regarding the nature and scope of this right see ALAN F. WESTIN, PRIVACY AND FREEDOM, 23-52, 330-365 (1967); PRIVACY: NOMOS XIII (J. Roland Pennock \& John W. Chapman eds., 1971); Ferdinand D. Schoeman, Privacy AND Social Freedom, 11-24 (1992); PhilosophicAl Dimensions OF PRIVACY - AN ANTHOlogy (Ferdinand D. Schoeman ed., 1984). See also infra Ch. 4b § 4.1.1 Origins of Privacy.

68 For a general discussion of the privacy aspect of information and its protection see Daniel J. Solove, Conceptualizing Privacy, 90 CALIF. L. REV. 1087, 1124-26 (2002); Julie E. Cohen, Examined Lives: Informational Privacy and the Subject as Object, 52 STAN. L. REV. 1373 (2000); Anita L. Allen, Privacy-as-Data Control: Conceptual, Practical and the Moral Limits of the Paradigm, 32 ConN. L. REv. 861 (2000). See also infra Ch. 4b § 4 - Information Privacy.

69 Raymond Wacks, Personal Information, 22 (1989).

$70 \quad$ Infra Ch. 4b § 4.2.2.3.3.1 - Medical Information.

71 Infra Ch. 2 notes $132-135$, Ch. 4b notes $68-70$, and Ch. $3 \S 3-$ The Outer Tier - Protection from External Interception. See also Israel Protection of Privacy Law, 1981 § 2(1) \& 2(3) (Isr.).

72 Edward B. Diskant, Comparative Corporate Criminal Liability: Exploring the Uniquely American Doctrine through Comparative Criminal Procedure, 118 YALE L.J. 126, 145-46 (2008). A common American approach is that of singular privacy for "individuals, not organizations," Peter J. Henning, The Conundrum of Corporate Criminal Liability: Seeking a Consistent Approach to the Constitutional Rights of Corporations in Criminal Prosecutions, 63 TENN. L. REV. 793, 841 (1996). 
Another social value expressed in the legal protection of information is building confidence between people. ${ }^{73}$ The law protects mainly special relationships, such as those of the family unit and those of patient-physician, patient-psychiatrist, client-attorney and congregantclergyman. ${ }^{74}$ Granting special status to communicative messages transferred within these frameworks, regulating control over them and preventing their unauthorized use or exposure play a central role in building fiduciary relations between parties to a relationship.

Interpersonal communication is also a social value that the law considers important. ${ }^{75}$ The activity is carried out through communicative messages, primarily speech, writing and electronic signals. The law protects interpersonal communication by ensuring the privacy of the basic communication channels, and generally prohibits electronic eavesdropping.

National security is another social value and interest, although its emphasis changes from one country to another. By nature, national security requires the preservation of the confidentiality of information and its sources. The law upholds this interest through a network of prohibitions and by limiting the unauthorized creation and collection of information of a confidential nature, and its unauthorized transfer to unqualified entities. ${ }^{76}$

Property, a central value in Western culture, concludes this partial list of rights and interests, the defense of which includes the protection of

73 Infra Ch. $3 \S 2$ - The Inner Tier - Protection against Exposure by Recipient. For the development of the legal notion of confidence see BRIAN C. Reid, Confidentiality and the Law (1986); TANya Aplin, Lionel Bently, Phillip Johnson \& Simon Malynicz, GurRy on BREACH of CONFIDENCE (2nd ed., 2012); Roger J. Toulson \& Charles M. Phipps, Confidentiality (2nd ed., 2006). For recognition of the "imperative need for confidence and trust" see Trammel v. U.S., 445 U.S. 40, 51 (1980) (C.J. Berger).

74 John H. Wigmore, Evidence in Trials at Common Law, vol. 8 § 2285 et seq. (rev. ed., John T. Mcmaughton ed., 1961); Special Project, Developments in the Law - Privileged Communications, 98 HARV. L. REV. 1450 (1985).

75 Peter Drahos, A Philosophy of Intellectual Property, 171 (1996) states that "information is the lifeblood of human agents as communicating beings ...."

76 Infra Ch. 4a $\S 2$ - National Security Information. See ThOMAS H. O'DELl, InVENTIONS AND OfFICIAL SECRECY: A History OF SECRET PATENTS IN the United Kingdom (1994); Rosamund M. Thomas, Espionage And SeCrecy: The Official SeCRets ACts 1911-1989 of the United Kingdom (1991). 
information. Property assumes many forms, ${ }^{77}$ some disputed, ${ }^{78}$ often as a result of transformations that followed changes and expansion of the forms of wealth in society throughout the ages. ${ }^{79}$ Initially, the tendency was to limit the concept of property and proprietary rights to a nexus between an individual and tangible assets. ${ }^{80}$ Later, property was perceived as an expression of a cluster of relationships between individuals and physical entities. ${ }^{81}$ According to the current prevailing approach, "the realization that property consists only of legal relations between people makes it clear that there is no need for any tangible object to serve as the object of those relations." 82 Thus, information can also have proprietary value and deserves proprietary protection. ${ }^{83}$ Indeed, the information at the heart of patents, copyrights and trade secrets constitutes intellectual

77 Although it is difficult to define property in exact terms, it is common to assume that possession, transfer and the exclusion of others are main types of rights bundled for its protection.

78 Hanoch Dagan, The Craft of Property, 91 CALIF. L. REv. 1517 (2003); Kevin Gray, Property in Thin Air, 50 CAMB. L.J. 252 (1991).

79 JAMES W. Ely JR., The Guardian OF Every Other Right: A CONSTItUtional History of PROPERTy Rights (BiCENTENNIAL ESSAYS ON THE BiLL of Rights), 6 (2nd ed., 1992). But $c f$. JoHn ChristMan, The Myth oF PROPERTY: TOWARD AN EGALITARIAN THEORY OF OWNERSHIP (1994).

80 WiLliam BLACKSTONE, COMMENTARIES ON THE LAW OF ENGLAND, vol. 2, ch. 1 (1765-69). On the decline of Blackstone's theory see Kenneth J. Vandevelde, The New Property of the Nineteenth Century: The Development of the Modern Concept of Property, 29 BufF. L. REV. 325, 328-29 (1980).

81 Wesely Newcomb Hohefeld, Fundamental Legal Conceptions, as APPliED IN JUdicial REASONING, 28-29 (Walter Wheeler Cook ed., 1923); Bruce A. ACKerman, ECONOMic Foundation of Property LAW (1975).

82 Arnold S. Weinrib, Information and Property, 38 U. ToRONTO L.J. 117, 120 (1988); Leif Wenar, The Concept of Property and the Takings Clause, 97 Colum. L. ReV. 1923, 1944 (1997).

83 Jacqueline Lipton, Information Property: Rights and Responsibilities, 56 Fla. L. REV. 135 (2004); Geraldine Szott Moohr, Federal Criminal Fraud and the Development of Intangible Property Rights in Information, 2000 U. ILL. L. REV. 683, 725 et seq. (2000); Eli Lederman, Criminal Liability for Breach of Confidential Information, 38 EMORY L.J. 921, 930 et seq. (1989). 
property, ${ }^{84}$ and its protection is rooted in the will of society to ensure that those who made the effort and the investment also bear the fruits. ${ }^{85}$

On closer examination, however, the nature of intangible objects, especially of trade secrets, is somewhat equivocal. Indeed the economic value of these types of information, the ability to commercialize them, the capacity to exercise absolute control over them, the possibility to inherit them and the authority to subject them to taxation, highlight their proprietary characteristics. But other fundamental characteristics of confidential information, such as its ability to extinguish itself (as upon publication of a trade secret), the possibility of devaluing it through reverse engineering and of duplicating it by transferring it to another, seem to indicate that at least trade secrets are not property in the regular sense of the term. ${ }^{86}$ This ambiguity is further underscored by a reluctance to accept that the right to information holds unlimited sway over the rights of a bona fide third party, as would a typical proprietary right. Additional uncertainty follows from different policy considerations regarding social progress, aimed at encouraging the flow of certain types of information that form the basis of the common pool of knowledge. ${ }^{87}$

Irresolution over a sweeping identification of the protection of confidential information with proprietary rights has bred several suggestions, like the one that regards a trade secret as an extension of the notion of property or as legally analogous with it. ${ }^{88}$ Lord Upjohn suggested classifying confidential information as equitable property, stating that information "is not property in any normal sense, but equity will restrain

84 Infra Ch. 4a $\$ 3$ - Confidential Commercial Information (Trade Secrets). On the tangible facets of information see Margaret Jane Radin, Information Tangibility, in ECONOMICS, LAW AND InTEllectual Property: SEeKING Strategies for Research and Teaching in a Developing Field, 395 (O. Granstrand ed., 2003).

85 "It is certainly not agreeable to natural justice that a stranger should reap the beneficial pecuniary produce of another man's work." Millar v. Taylor (1769) 4 Burr. 2303, 2334; 98 E.R. 201, 218 (Willes J.) (cited in Robert L. DEAN, THE LAW OF TRADE SECRETS, 3 (1990)).

86 Roger W. De Vries, Towards a European Unfair Competition LaW: A Clash Between Legal Families, 273-75 (2006); John T. Cross, Trade Secrets, Confidential Information, and the Criminal Law, 36 MCGILL L.J. 524, 534-35 (1991); N.E. Palmer, Information As Property, in CONFIDENTIALITY AND THE LAW, 83 (Linda Clarke ed., 1990).

87 R. Grant Hammond, Quantum Physics, Econometric Models and Property Rights to Information, 27 MCGILL L.J. 47, 54 et seq. (1981).

88 Jeremy Waldron, The Right to Private Property, 33 et seq. (1988). 
its transmission to another if in breach of some confidential relationship."89 Scholars of common law worldwide who wish to protect trade secrets, but find it difficult to regard them as property in the strict sense, tend to adopt this approach. ${ }^{90}$ Others question whether in practice it is meaningful to define trade secrets as property. ${ }^{91}$ The equitable property approach, however, raises difficulties as long as the law has not created a separate collection of rules to protect trade secrets. ${ }^{92}$

The position that prefers to regard different types of information, including trade secrets, as property and grant them proprietary protection gained strong support in court. ${ }^{93}$ It broadened the scope of protection and opened the way to the examination of additional growing categories of information, including personal data, as property. ${ }^{94}$

The dispute about the extent of the information that has proprietary value echoes the disagreement about the quality and status of the term "property" in the structure of basic rights. A school of thought that preserves the requirement of economic value of tangible and intangible assets narrows the quality and status of the proprietary right and tends to regard it as a separate right that stands together with other basic rights in an inclusive structure. By contrast, the expansive approach, which eases the requirement of economic value, can regard the proprietary right as a

89 Boardman v. Phipps, [1966] 3 All E.R. 721, 759; A.G. Guardian Newspapers Limited (No. 2), [1988] 3 All E.R. 545, 658.

90 William CORNish, DAVID LleWElyn \& TANYA APLin, INTEllectual Property: Patents, Copyright, Trade Marks AND Allied Rights, 351, 352-54 (8th ed., 2013); John Hull, Trade Secret Licensing: The Art of the Possible, 4 J. Intell. Prop. L. \& Practice, 203 (2009).

91 See the broader line of argument referring to the protection of intellectual property in Stephen L. Carter, Does It Matter Whether Intellectual Property is Property?, 68 CHI.-KENT L. REV. 715, 716 (1993).

92 Cross, supra note 86, at 539-40.

93 The US Supreme Court has classified information as property. Ruckelshaus v. Monsanto, 467 U.S. 986, 1001-04 (1984) and Carpenter v. U.S., 484 U.S. 19, 26 (1987). See also the changing needs of the treatment of information, Pamela Samuelson, Information as Property: Do Ruckelshaus and Carpenter Signal a Changing Direction in Intellectual Property Law?, 38 CATH. U. L. REV. 365 (1989).

94 Westin, supra note 67, at 324-25; MARgAREt JANE RADIN, REINTERPRETING PROPERTY, 35-37, 40 (1993). Radin distinguishes between fungible property and personal property, which is "closely bound up with personhood." See also Pamela Samuelson, Privacy as Intellectual Property?, 52 StAN. L. REV. 1125 (2000); Infra Ch. 4b notes 492-493 and text accompanying. For a critique of the property model see Jessica Litman, Information Privacy/Information Property, 52 StAN. L. REV. 1283, 1289 et seq. (2000). 
primary inclusive right based on the most elementary layer of the entire structure of rights. ${ }^{95}$ Such a primary right can serve at times as a starting point for additional derivative rights. ${ }^{96}$ According to this expansive approach, personal information concerning the individual deserves protection not only because of the right to privacy but also because it includes a distinct, primary proprietary layer despite its lack of economic value in view of the close relationship between the individual and the information under consideration. ${ }^{97}$

\subsection{Balancing Rights, Values and Interests}

The theory of rights tends to assume that almost no right is absolute. In this area, as in others, "we are faced with choices between ends equally ultimate, and claims equally absolute, the realization of which must inevitably involve the sacrifice of others."98 The law usually rules on conflicts between rights by weighing and balancing them. ${ }^{99}$ The principles and interests that reflect the protection of protecting information also compete with other interests that are in favor of its disclosure and free flow. Because information plays an important role in various aspects of life, "there are tensions between spheres in the roles we expect information to play." 100

95 Ayn Rand, Man's Rights, in Ayn Rand, The Virtue of SElfishness: A NEw CONCEPT OF EGOISM, 108, 110 (1964). For an analysis of property rights emphasizing its special position in the structure of civil rights see STEPHEN R. Munzer, A THEORY OF Property, 48 et seq. (1992); Richard A. Epstein, Property as a Fundamental Civil Right, 29 CAL. WEST. L. REV. 187 (1992).

96 Judith Jarvis Thomson, The Right to Privacy, 4 PHIL. \& PuB. AfF. 295, 306 312-14 (1975). But cf. Julie C. InNESS, PRIVACY, InTIMACY AND IsOlation, 36 (1992).

97 Margaret Jane Radin, Property and Personhood, 34 Stan. L. REV. 957, 986 (1982). For a view that frees privacy from its link to property and emphasizes its value as a safeguard of personhood see Jed Rubenfield, The Right of Privacy, 102 HARV. L. REV. 737 (1989).

98 ISAIAH BERLIN, Two Concepts of Liberty, in FOUR ESSAYS ON LIBERTY, 118, 168 (1969), http://www.wiso.unihamburg.de/fileadmin/wiso_vwl/johannes/ Ankuendigungen/Berlin_twoconceptsofliberty.pdf. (seen Mar. 2, 2015).

99 Balancing Conflicting Rights: Towards an Analytical Framework (Ontario Human Rights Commission, 2005), http://www.ohrc.on.ca/ta/book/export/html/ 2476 (seen Aug. 8, 2015); Conflicts Between Fundamental Rights (Eva Brems ed., 2008); Jeremy Waldron, Rights in Conflict, 99 ETHICS 503 (1989).

100 James Boyle, A Theory of Law and Information: Copyright Spleens, Blackmail, and Insider Trading, 80 CAL. L. REV. 1415, 1438 (1992). 
Among the rights and interests that reflect the need for at least partial exposure and free flow of information are progress and economic efficiency. Almost every development is based on information or knowledge, and every previous discovery and development may serve as a basis for subsequent ones. If in the name of the right to property we allow thinkers and entrepreneurs to preserve their ideas indefinitely, barring others from using them without permission, we hinder the development of these ideas. The result would be harmful to the collective development and efficiency of the economy because financial resources, time and effort may end up being invested into channels leading to outcomes that are already part of our patrimony.

Furthermore, against every right that favors the protection of information stand the basic right to freedom of expression and its various derivatives, such as the right to know in general and freedom of the press in particular. Freedom of expression focuses on the free flow of information and underlines such objectives as free society and free interchange of ideas, human liberty and self-actualization, freedom of communication, informed citizenry and open government. The diverse aspects of this value include all three gradually widening circles of the right: (a) the inner circle of an individual's right to obtain access to his personal records collected and maintained by government agencies and to ensure the accuracy of the information; ${ }^{101}$ (b) a wider circle embracing the individual's right to access non-classified information in the possession of his government; ${ }^{102}$ and (c) the widest circle encompassing the

1015 U.S.C. $\$ 552 \mathrm{a}(\mathrm{d})$ (The Privacy Act of 1974). For a brief description see Alex Kardon, Damages under the Privacy Act: Sovereign Immunity and a Call for Legislative Reform, 34 HARV. J.L. \& PUB. POL'Y 705, 706-08 (2011); infra Ch. 4b § 4.2.2.3.2 - Governmental Authorities and Agencies.

102 Harold L. Cross, The People's Right to Know; Legal Access to Public RECORDS AND PROCEEDINGS (1953). For an examination of some aspects of this issue under the Freedom of Information Act (FOIA), 5 U.S.C. $§ 552$ (1996) see HERBERT N. FOERSTEL, FREEDOM OF INFORMATION AND THE RIGHT TO KNOW: ThE ORIGINS AND APPLICATIONS OF THE FREEDOM OF INFORMATION ACT (1999). For the UK perspective see THE LAW OF FREEDOM OF INFORMATION (2nd ed., John Macdonald, Ross Crail \& Clive Jones eds., 2009). For international comparative surveys on the topic see TOBy MENDEL, FreEdom OF Information: A COMPARATIVE LEgAL SuRvey (2nd ed., 2008), http:// www.fas.org/sgp/foia/comparative.pdf (seen Mar. 2, 2015). See also infra Ch. 4a $\S 2$ - National Security Information, text accompanying notes 8-9. 
individual's right to access information of general and public concern, a right specifically protected by a free press. ${ }^{103}$

Some aspects of freedom of expression are at odds with the perception of information in proprietary terms. Neither do these aspects agree with other interests that demand, each within its own context, to tilt the balance in favor of the protection of information, and prefer to grant the right to control the information to other agents for reasons of privacy, ${ }^{104}$ good reputation, fairness to the individual, ${ }^{105}$ protection of national security, ${ }^{106}$ fair trial, ${ }^{107}$ efficiency of government agencies and confidence-based interpersonal agreements or communication. ${ }^{108}$

The quality and extent of the protection of information and of its sources in various contexts are a result of balancing the values and interests mentioned earlier with other forces to which the legal system is committed and that form our social infrastructure. ${ }^{109}$ This balancing of

103 On the first amendment and the right to know see LEONARD W. LEVY, EMERGENCE OF A Free Press (1985); Sigman L. Splichal, The Right to Know, in ACCESS DENIED: FREEDOM OF INFORMATION IN THE INFORMATION AGE, 3 (Charles N. Davis \& Sigman L. Splichal eds., 2000).

104 Daniel J. Solove \& PaUl M. Schwartz, Privacy And the Media (2008); Scott J. Shackelford, Fragile Merchandise: A Comparative Analysis of the Privacy Rights for Public Figures, 49 Am. Bus. L.J. 125 (2012).

105 Daniel J. Solove, The Future of Reputation: Gossip, Rumor, And PRIVACY ON THE INTERNET (2007); Robert D. Richards, Sex, Lies, and the Internet: Balancing First Amendment Interests, Reputational Harm, and Privacy in the Age of Blogs and Social Networking Sites, 8 FIRST AmEND. L. REV. 176 (2009).

106 SECRECY AND LIBERTY: NATIONAL SECURITY, FrEEDOM OF EXPRESSION

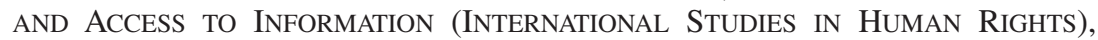
477-507 (Sandra Coliver, Paul Hoffman \& Joan Fiztpatrick eds., 1999); MORTON H. HAlperin \& Daniel N. HofFMan, Top Secret: NATIONAl SECURity AND The Right to Know (1977); Daniel J. Solove, Nothing to Hide: The False TRADEOFF BETWEEN PRIVACY AND SECURITY, 62-71 (2011).

107 Danny J. Boggs, The Right to a Fair Trial, 1998 U. CHI. Legal F. 1; David A. Strauss, Why it's not Free Speech Versus Fair Trial, 1998 U. CHI. Legal F. 109; Giorgio Resta, Trying Cases in the Media: A Comparative Overview, 71 LAW \& CONTEMP. PROB. 31 (2008).

108 Richard A. Epstein, Privacy, Publication, and the First Amendment: The Dangers of First Amendment Exceptionalism, 52 STAN. L. REV. 1003, 1047 (2000); Eugene Volokh, Freedom of Speech and Information Privacy: The Troubling Implications of a Right to Stop People From Speaking About You, 52 StAN. L. REV. 1049, 1057-63 (2000).

109 Supra note 99. 
intersecting or colliding norms may bring to light issues of proportionality that determine the extent of the right and the capacity to exercise it. ${ }^{110}$ The process frequently involves the legislature and to an even greater extent, the courts. It usually begins at the level of the definition of a principle, where the various values and rights do not necessarily carry the same weight. ${ }^{111}$ The balancing process expresses the relative position of rights in the hierarchy of moral and social values in a given society and legal system. Moreover, the process reflects the weight that may be granted to the circumstances of the events and their possible implications. ${ }^{112}$

In the absence of a basic mechanism that serves as a uniform source for all balances and of a supreme norm that serves as a model for information protection, the entire process is subject to context and preferences. The type of checks and balances applied in the criminal area is not always identical to those used in civil law, which itself is not monolithic. ${ }^{113}$ Naturally, legal policy and judicial discretion play a central role in this mechanism. To some extent, the process resembles a parallelogram of forces in physics, where each vector represents one of the rights or interests involved. The length of the vectors shows the relative strength of these interests against the background of a given legal system. The direction of the vectors and the angle between them express the extent of the conceptual differences between these social forces, and the diagonal represents the resulting balance.

110 For the roles of balancing and proportionality see ROBERT ALEXY, A THEORY OF CONSTITUTIONAL Rights, 394-425 (Julian Rivers, trans., 2002); Bernhard Schlink, Proportionality in Constitutional Law: Why Everywhere But Here?, 22 Duke J. Comp. \& InT'L L. 291 (2012); Jud Mathews \& Alec Stone Sweet, All Things in Proportion? American Rights Review and the Problem of Balancing, 60 EMORY L.J. 797 (2011).

111 If fixed hierarchies of rights and values could be constructed there would be no use for a balancing mechanism. Mathews \& Sweet, ibid., at 805 (2011).

112 For some aspects of the balancing and the proportionality process see Grégoire C.N. Webber, Proportionality, Balancing, and the Cult of Constitutional Rights Scholarship, 23 CAN. J. L. \& JuR. 179 (2010). See also the two symposium issues on Rights, Balancing \& Proportionality, 4 LAW \& ETHICS HuM. RTS. 1 (2010).

113 See the interpretation and assessment of different legal systems of the right of expression and the right of association examined by Larry Cata Backer, Disciplining Judicial Interpretation of Fundamental Rights: First Amendment Decadence in Southworth and Boy Scouts of America and European Alternatives, 36 TULSA L.J. 117, 120-22 (2000). 
An economic dimension can be added to this complex system of value considerations. Some scholars believe that under the influence of technology, modern society is rapidly becoming an open structure in which the vast majority of stored information is available to all members. This vision is not a result of social trends, which are often transitory, but rather of the scientific-technological revolution in the means of information processing and transfer. In a society in which almost all computers are online, the cost of protecting information systems from unauthorized access may become economically inefficient. Some specialists predict that in the future electronic commerce and the provision of services through computers will dominate the economy, and alternatives for the transfer of goods and services may diminish. If carried to the extreme, this situation could eventually turn almost every computer and database into an open source because the protection of the confidentiality of its content will be more costly than the damage resulting from its exposure. ${ }^{114}$

\section{SCOPE AND PURPOSE OF THE STUDY}

\subsection{Scope}

The study examines the protection of confidential information by substantive criminal law. As noted, we include communicative messages under the term "information" due to a natural tendency to integrate the two. At times, the term "source of information" serves as a phrase inclusive of all sources of information, and in other contexts it points to the residual group of sources, excluding communicative messages. ${ }^{115}$ The expression "information and its sources" serves usually as an inclusive term that comprises both information and all types of sources of information.

In the context of this study, confidential information refers first and foremost to non-public information. The initial determination of what is confidential rests with the holder of the source of information, and the law generally honors his decision. In other contexts, however, for example in the case of trade secrets or certain cases of secret monitoring, this subjective basis is complemented by the need to meet objective criteria. In many cases the confidential information is being held by its

114 Niv Ahituv, The Open Information Society: The Final Step on the Internet Route, 44(6) COMMU. OF THE ACM. 48 (June 2001).

115 Supra text accompanying note 43. 
owner, but this is not always the case. In both situations, the information is instantiated as a tangible or intangible entity (communicative message, occurrence, event, and so on) and can serve as a source of information for any potential acquirer.

For the purposes of the present study we imposed three restrictions on the scope of inquiry:

1. The study is limited to a category of cases in which the legal system has determined that the values and rights favoring the preservation of confidentiality of information outweigh the interests that require at least its partial disclosure. The study does not address the process by which the checks and balances have led to the legal policy determination by weighing the principles involved, a process carried out either by the legislative or by the judicial function. As a result, various issues have been taken out of the discussion. In general, the cases removed fall into three main categories in which a demand exists to reveal the information:

a. Cases in which the law imposes an explicit duty on the relevant authority to disclose information regarding an individual, despite the fact that he may prefer not to disseminate it, ${ }^{116}$ as when the information is intended to notify the public or to allow the public to object to an action and to prevent results that may be difficult to reverse later. But the study addresses situations like the registration of sex offenders, in which the public notification is an exception to the rule that safeguards the confidentiality of personal information. ${ }^{117}$

b. Cases in which the law imposes an explicit duty on the information holder to disclose it to a government agency on his own initiative, despite the fact that he or those who have an interest in the information (for example, those to whom the information refers) may be interested in preserving its confidentiality. The recipient agency may need the information in the course of its work. One subset of these cases, in which the regular use of the information by the recipient may require its

116 At times the publicity refers to a government initiative regarding a certain person, for example his nomination to a public position; at other times, the disclosure makes public a notification sent by a person to the government or a request from it, for example a request that the court issue a declaration of presumed death in case of a missing person.

117 Infra Ch. 4b $\S$ 4.2.2.3.2.4 - Criminal Record, text accompanying notes $841-891$. 
exposure, as in the case of reports on involvement in certain traffic or workplace accidents, ${ }^{118}$ falls outside the limits of this work. Another subset, in which the regular use of the information does not involve its exposure, like tax returns or statistical records, is addressed in Chapter 4. In this last group of cases the issue of preserving the confidentiality of the provided personal information remains. ${ }^{119}$

c. Cases such as legal search and seizure by law-enforcement personnel or authorized secret monitoring, in which the law allows the formation and collection of information from various sources, even if the holder of the information or the person who has an interest in it has not given his consent or may not even know that the information is being collected. The collection of information is often carried out with the intent to directly harm the holder of the information or its source. Favoring the disclosure of information in these cases is the imperative to safeguard public safety and welfare, and the desire to ensure the efficiency of the authorities, even if it consciously injures the privacy or property rights of the individual who holds the information or of the person to whom the information refers. ${ }^{120}$

2. The second limitation has to do with divisions within the legal discipline and with the mode of protection. The present analysis does not widen its examination beyond the criminal arena, although it is reasonable to assume that some of the models presented here may be applicable also to branches of civil law. Moreover, the discussion has been restricted to information kept in confidence, which is not "common knowledge." The study does not address such types of information as copyrights, patents and trademarks, where the law protects rights and interests for a limited period of

118 See Israel Accidents and Occupational Diseases (Notification) Ordinance, $1945 \S 3$ (Isr.). Other examples of this type are the requirement to answer police questions in an interrogation or the obligation to testify in court if summoned subject to limitations such as the privileges against self-incrimination. This information can serve police investigations and legal proceedings and cannot be considered confidential.

119 Infra Ch. 4b $§$ 4.2.2.3.2 - Governmental Authorities and Agencies.

120 Law-enforcement personnel are often also authorized to transfer the information collected by government agencies. 
time, while the public enjoys access rights to the information for limited use. ${ }^{121}$

3. The third restriction relates to the mode of protection of the information. Confidentiality is protected in the criminal arena by two methods, based on the severity of the measures of enforcement: law of evidence and substantive criminal law. The study limits itself to the second method, with the exception of confidence-based interpersonal communication, where evidentiary measures are addressed as part of the model and play an important role in the structure of the protection established by it. ${ }^{122}$

The law of evidence protects indirectly confidential information against undesired exposure; it maintains the propriety of the legal process and at the same time determines that certain information is privileged ${ }^{123}$ or disqualified as legal evidence. ${ }^{124}$ The scope of the protection is limited, however, and effective only when the acquisition of information is aimed at obtaining evidence to be presented in court. But the concept of inadmissibility loses significance when the acquisition of information is aimed to satisfy the curiosity of an individual or to assist him in making a decision. The protection of information through the law of evidence emphasizes the willingness of society to renounce the search for truth in

121 Lionel Bently \& Brad Sherman, Intellectual Property LaW, 323 (2nd ed., 2004); CORNISH, LLEWELYN \& APLIN, supra note 90, at 6-9.

122 Infra. Ch. $3 \S 2.2$ - Review, Examination and Classification and Ch. 3 $\S 2.3$ - The Scope of the Protection of Confidential Communication.

123 Some privileges recognize the right of an information holder not to disclose it without the consent of the persons who are subjects of the information, even if it is required as evidence in criminal court. An example is the privilege against self-incrimination (HANNAH QUIRK, THE RIGHT TO SILENCE, Principle, Pragmatism AND POlicy MAKING (2014)). When the information holder and the individual with the interest in it are different entities, the privilege is aimed at bolstering confidence in sensitive trust relationships. Infra $\mathrm{Ch}$. $3 \S 2.2$ - Review, Examination and Classification and Ch. $3 \S 2.3$ - The Scope of the Protection of Confidential Communication.

124 Declaring illegally obtained information to be inadmissible as evidence is another facet of protecting information by frustrating the purpose of exposing it in court. For example, information collected by wiretapping without a court order. Clifford S. Fishman \& AnNe T. MCKenNa, WiretapPing AND EAVESDROPPING, Surveillance In THE InTERnet Age (3rd ed., 2007). Similarly, according to the exclusionary rule, information obtained by illegal search and seizure or by improper methods is inadmissible in court. THOMAS K. CLANCY, The Fourth AMENDMENT: ITS History AND InTERPRETATION, ch. 13 (2008). 
the judicial process for the sake of preserving the social value incorporated in the protection.

The second method of protecting information imposes direct coercive restrictions on its acquisition and use or disclosure by means of substantive law, so that an individual who breaches the confidentiality of information may be held criminally liable. Under the aegis of substantive law, taking civil action does not preclude criminal measures, and vice versa. The possibility of a contractual or tort suit filed by a patient against his physician in case of unauthorized disclosure of confidential medical information does not prevent criminal charges against the physician for breach of privacy, in legal systems that acknowledge this offense. Similarly, the procedural method of protecting information can be used in both civil and criminal proceedings. For example, the exclusion of illegally obtained evidence can exist alongside a possible criminal charge and civil suit against the discloser of the information. All these possible combinations enhance the deterrence afforded by the various methods of protecting information.

The present study focuses on the substantive mode of protection through criminal law and attempts to delineate and analyze the main patterns of criminal provisions that protect confidential information from unauthorized acquisition, use or disclosure. In addition to the common use of well-known offenses designed to protect information, like espionage, ${ }^{125}$ peeping and opening of sealed letters, ${ }^{126}$ legal systems have not hesitated, especially since the mid-20th century, to enact provisions aimed at protecting confidentiality in specific situations. At times, they have expanded the framework of known criminal structures (like trespass, espionage and theft) to include the protection of information within their boundaries (computer trespass, ${ }^{127}$ commercial espionage ${ }^{128}$ and theft of information $\left.{ }^{129}\right)$. At other times, legislators have formed new criminal provisions for the protection of information, for example offenses

\footnotetext{
125 Infra Ch. 4a $§ 2.3 .1 .2$ - Espionage.

126 Infra Ch. 2 2.2.3 - Trespass and Peeping - The Protected Spaces and Ch. $2 \S 2.3$ - Interception of Communicative Messages.

127 Infra Ch. 2 \$3.2.2 - Unauthorized Access to the Protected Space.

128 Infra Ch. 4a $\$ 3$ - Confidential Commercial Information (Trade Secrets), text accompanying note 241 et seq.

129 This offense protects information as a sort of proprietary substance when common theft is inapplicable to intangible matters. In this case, the emphasis shifts to protecting control over information which is lost following the unwanted acquisition, use or disclosure.
} 
designed to cope with various aspects of preserving privacy by limiting unauthorized surveillance or eavesdropping.

In sum, the study focuses on non-public information for which the penal code provides protection to those who have a legitimate interest in it. In specific situations, when it is possible to apply an organizational disciplinary code as well, the provisions of these internal, quasi-criminal codes are also applied. ${ }^{130}$

The practical way of protecting confidential information is to restrict the ability of unauthorized individuals to use or disclose non-public information of which they are aware, and to limit their ability to create or collect such information of which they are unaware. Prohibitions against accessing information limit the use that individuals can make of their senses; this method is therefore used with caution.

The objects of protection are the parties with an established right or interest in the given confidential information. These parties usually hold the source of information. Under certain circumstances the protection also extends to the party to whom the information refers, even if that party is not in possession of the information, for example a confidential report evaluating the professional performance of an individual prepared by his supervisor. In some cases, the protection embraces human beings as well as legal entities. At other times, it applies first and foremost to corporations and states that hold information and its sources through authorized agencies, as in the case of trade secrets and national security information.

The essence of protection is the recognition of the right of a party to control the dissemination of non-public information in which he has a legal interest. The formal expression of this control is the legal power to limit the capacity of another to acquire information from a source that is an object of protection, and, if the other has already acquired the information, to prohibit him from using or disclosing it without the authorization of the owner of the interest.

The ability of one party to limit the freedom of another to acquire or use information is not the equivalent of that party's total right to the said information. A party's right to information has a special, narrower meaning. It is not an inclusive in rem property right, valid against every third party, for exclusive possession and use of the information. ${ }^{131}$ The

130 Infra Ch. $3 \S 2.2$ - Review, Examination and Classification and Ch. 3 $\S 2.3$ - The Scope of the Protection of Confidential Communication.

131 As long as the owner of the right does not disclose it. Miguel Deutch, The Property Concept of Trade Secrets in Anglo-American Law: An Ongoing Debate, 31 U. RICH. L. REV. 313, 318-19 (1997). 
right is restricted to the ability to prevent others from obtaining the information by improper means. If an individual or organization discovers this information in a manner that is not flawed, say, accidentally or by independent development, the original possessor loses his exclusive right to it. 132 Protected information can, therefore, remain such for an unlimited period of time, but it can also become the possession of others and even be placed in the public domain in a legal process that takes place against the wishes of the original owner. ${ }^{133}$

Honoring the decision of a party to control access to non-public information and its sources is not the sole reason for imposing criminal sanctions on unauthorized acquisition of information from a protected source. The legislator may have additional incentives for doing so, even if there is no opposition on the part of the holder of the information or of other parties with an interest in it. This is the case, for example, when the aggregate weight of a large-scale accumulation of data produces a pool of information that can harm the privacy of individuals, even if separate items in this collection are not potentially harmful. ${ }^{134}$ This case becomes more significant when the information is collected from public sources, primarily the Internet. These and similar situations having to do with the "ecology" of the information environment are beyond the scope of the present inquiry. This study is restricted to the protection of non-public information over which the holder or the individual to whom the information refers can exercise some control. The topic of illicit combinations of items that individually are not harmful to the privacy of individuals needs to be regulated by the legislator. Administrative law or the penal code can be used to prevent the formation of social hazards that exceed the individual's area of control. ${ }^{135}$

132 Kewanee Oil Co. v. Bicron Corp., 416 U.S. 470, 475-76 (1974); Defiance Button Machine Co. v. C \& C Metal Products Corp., 759 F.2d 1053, 1063 (2d Cir. 1985), 474 U.S. 844 (1985).

133 Geraldine Szott Moohr, The Problematic Role of Criminal Law in Regulating Use of Information: The Case of the Economic Espionage Act, 80 N.C.L. REV. 853, 868 (2002).

134 Julie E. Cohen, The Unwanted Gaze, by Jeffrey Rosen: Privacy, Ideology, and Technology: A Response to Jeffrey Rosen, 89 GEO. L.J. 2029 (2001).

135 See the discussion regarding data mining infra $\mathrm{Ch}$. $4 \mathrm{~b}$ \$ 4.2.2.1.2 Acquisition of Personal Information, notes 602-612 and text accompanying. 


\subsection{Purpose}

This study aims to establish a structure that describes the prominent forms of protection of confidential information through substantive criminal law. It examines the essence and extent of the protection using three models that reflect the main patterns used by criminal law provisions to protect confidential information and its sources from unwanted acquisition, use or disclosure. The study is based mostly on American federal and state law, with occasional reference to UK and EU legislation. This unified and conceptually coherent structure emphasizes the content of the provisions and endows them with greater pith and moment than the provisions themselves individually possess. In this way, the organized structure reinforces the aims and values that the provisions intended to protect.

The structure proposed in the study underlines yet another angle that derives from the "form and substance" relations in law. Research in medicine and life sciences has formulated an approach whereby to understand the function one must study the structure. ${ }^{136}$ This approach describes a method of research of living organisms that begins by exposing and understanding that which already exists. Structure is the starting point of the research process because it is the existing reality. The assumption underlying any investigation in medicine and life sciences is that any existing structure shows utmost efficiency in fulfilling a specific function, because in the world of flora and fauna there are no spurious structures or nonfunctional arrays. Research, therefore, begins with understanding the structure and the potential it holds, and proceeds with an investigation of the practical aim that the structure fulfills. The picture is radically different in the legal field, because society has the power both to create the structure and to shape the content. Structure and substance hold a complicated and ongoing dialog in law. Each can and must serve as a basis for understanding the other, and at the same time serve as an instrument for the analysis of reality and its directions of development.

Delineating a comprehensive structure based on existing provisions of law reveals the lines of reasoning and the basic common ideas and objectives underlying these provisions. In this manner, the legal substance, namely content, shapes structure. Conversely, as the essentials of the formal structure crystallize into a self-consistent unity, form begins to

136 Francis Crick, What Mad Pursuit: A Personal View of Scientific DISCOVERY, 150 (1988). 
affect content. It is possible to verify the extent to which the content of provisions matches the structure, and the contribution of content to the general ideas and objectives of the structure. Thus, policymakers can rely on the structure to determine the desired content and scope of provisions of law, and can deliberately deviate from the structure and modify it, adding or taking away content as dictated by real-life needs reflected in the law, so that the content affects the structure once again.

The values, rights and interests that support the protection of information are not analyzed directly and systematically, although their presence is clearly felt throughout the discussion. The protection of these rights and values is reflected in a variety of offenses discussed in the study. Criminal legislation consists of provisions that prohibit or mandate specific acts. A general provision that prohibits injury to a value or an interest from every possible angle is liable, because of its vagueness and lack of focus, to harm the fundamental principle of legality. At the same time, if emphasizing the values, rights and interests involved in the protection of information in each offense were to become a principal concern of the study, it may obscure its original emphasis and result in unnecessary repetition.

The study is an effort to aggregate under one structure unconnected provisions that have been enacted at different times, for diverse reasons, by various authorities, not all intended originally to deal directly with information. In many cases, it is difficult to follow the trends and connections involved, and the process evolves inductively from suppositions and assumptions. It has been said that criminal law "is a peculiar amalgam of old procedures, half-forgotten fears and the accidental survivals of the common law."137 Many criminal structures and ordinances, including those dealing with information, contain expressions of public notions and values alongside remnants of sectarian interests.

Assembling the separate pieces into a larger, more comprehensive structure, however, attests to the presence of an internal, perhaps hidden, rationale governing the protection of information. Is it also possible that, despite all external sociocultural and political forces, there is a primary conceptual similarity between the processes that balance the values and interests concerning information, a similarity that spans great distances of time and place? In parallel, such a structure can point to the flexibility of the law and its ability to adjust itself to changing needs and circumstances that follow from changes in sociocultural priorities and scientific

137 Lindsay Farmer, Criminal LaW, Tradition AND Legal Order: Crime AND the Genius of Scots LAW, 1747 to the Present, 183 (1997). 
development. Finally, there may be a basis for the argument that in this area, as in others, a large-scale social equilibrium prevails, owing to an "invisible hand" that counterbalances and neutralizes divergent forces. ${ }^{138}$ Within this framework of constraints and qualifications, the study purports to contribute to the shaping of a general and inclusive theory of protection of information.

We analyze the substance and scope of the protection granted to confidential information through criminal law by focusing on the basis for the legal right of a party to control the objects of protection. The prerequisites for the protection are conceptualized within the framework of three basic models: a spatial, a communicative and a content-based one. The conditions for the formation of each of these, as well as their extent and direction of development, are explored in Chapters 2, 3 and 4. There is a partial overlap between the models and the established rights and interests. It cannot be determined globally that every model uniquely represents a certain right, interest or value. The balanced and weighted rights are reflected mostly in horizontal sections that cut across the different provisions with which the three models are concerned.

The study investigates the relationship between law and information. Unlike part of the research in the field, it does not attempt to examine or analyze a particular issue but discusses the multiple facets of a theme common to many provisions in a variety of areas of criminal law. In other words, it deals with a cross-section of a broad subject rather than with an in-depth analysis of a narrow segment of a topic. Alongside the intriguing and valuable efforts that have been expended for the detailed examination of individual issues, "transaxial" investigation that cuts across issues is in order. The suggested models are naturally open to critique, and the structure as a whole may be rejected or supplanted by an alternative scheme. Any ensuing discussion about the protection of information by means of criminal law, or about other general subjects at the intersection of law and information, will have satisfied one of the main objectives of this study.

\section{MODELS OF PROTECTION}

The right of the holder of an interest in information or in a source of information to control it is based on a nexus recognized by law, which links him with a relevant circumstantial-factual element. This element

138 William J. Stuntz, The Uneasy Relationship between Criminal Procedure and Criminal Justice, 107 YALE L.J. 1 (1997). 
can be either (a) the place in which the source of information is located; (b) the manner or circumstances in which the information is transferred, or the identity of the individual who undermines control over the information or its sources; or (c) the content of the information. Each set of conditions for the establishment of such a nexus can be described formally as a model of protection of information and its sources.

From a formal legal perspective that analyzes the structure of the offenses that directly or indirectly protect information, the models deal mostly with objective circumstantial-factual elements of actus reus that are part of the definition of the relevant offenses. When the right of a party that holds an interest in the information or its source is crystallized, the conditions required by one of the models are established. If the party chooses to exercise its right, or there is a legal presumption that it does so, the prohibition protects its control of the information and may prohibit others from accessing or disclosing it without authorization.

In the first model, the nexus is between the interest holder and some setting that contains the source of information. This setting constitutes a protected space, and the nexus of the interest holder to the space is the basis for his right to prevent others from accessing the source of information without permission.

In the second model, the nexus is between the interest holder and specific communication processes. Under certain conditions, the process or channel of communication protects the information transferred by it from unauthorized exposure. The party transferring the message may control it to some extent both during and after its transmission. The basis for the right to control the information within this model varies. At times it is a function of personal relations between the communicating parties. For example, a trust relationship can serve as a basis for requiring the recipient not to undermine the control of the transferring party. In other situations, the control is a function of the mode of communication or its circumstances. Communicators who reveal their intention not to make the exchange of information public can prevent others from intercepting the information by mechanical means, while in transit.

In the third model, the content endows the information (the subject matter) with a subjective or objective importance that invests the interest holder with the right to prevent others from accessing the source of information, or to prevent lawful but restricted holders of the information from revealing or using it in unauthorized ways. Each one of these prohibited modes of behavior can serve as a basis for the imposition of criminal liability. 
The three suggested models do not form a closed or final list. Despite the theoretical distinctions between them, in practice the external boundaries of the models are not always distinct, and their internal subdivision is at times hazy. Moreover, the manner and direction in which the models develop can further blur their boundaries and widen the areas of overlap. ${ }^{139}$ The relative instability of the overall structure reflects needs and legal approaches that are naturally in motion and subject to change. The models have developed over the years in light of social, economic and technological changes, and represent directions of development in the preservation of information that have left their mark on our culture and way of life.

The requirements of the first model are mostly technical, and deal with the mere presence of the source of information within the limits of a protected space. The quality and substance of that source or the content of the information contained in it are not examined. In the other two models, the right of control over the protected object may require an analysis of the value of the information, or the context within which it was acquired or transferred.

The essence of the right of the interest holder to control the information or its sources also differs in the three models. In the spatial model, this right focuses on the authority of the interest holder to prevent others from gaining access to the source of the information. The other two models may prohibit also the unauthorized use or exposure of the protected information, so that the right can be expressed also in the authority to prevent those who have legally gained access to the information from using or disclosing it without permission.

Because of differences in their character, the three models are not mutually exclusive. Many situations can meet the requirements of more than one model and can be simultaneously covered by two or even all three models. In such a case, every model seeks the circumstantial derivative relevant to its requirements. For example, it is possible for a document containing confidential commercial information which is stored on the premises of the interest holder to be protected by the spatial model as a result of the nexus of the interest holder with the place where the document is stored, and at the same time by the content model as a result of the nexus that links the individual to the content of the document. In another instance, both the communication and content models protect information of an obviously personal nature given by a

139 Infra Ch. $3 \S 1.2$ - Origins and Relations; Ch. 4b $\S 4.2 .1$ - General Provisions - Indirect Protection and Ch. 4b $\S$ 4.2.2.3.1 - General. 
patient to a psychiatrist over the phone from secret monitoring by a third party and from unauthorized exposure by the receiving party. Similar situations of double and simultaneous protection can also be formed within the frameworks of a single model that contains several subsets, so that more than one subset of the same model protects the same information in parallel and for different reasons. This overlap does not undermine the validity of the schema, but, as the following chapters reveal, merely points to the rich substrate of experience that forms the object of protection. 